\title{
Effect of Stocking Density and Light Intensity on Feed Efficiency of Caged Broilers
}

\author{
Sujeet Kumar Yadav ${ }^{1}$, Ramesh Pandey*, Neeraj ${ }^{\#}$ \\ ${ }^{1}$ Ph.D. Scholar, Deptt. of Sundaresan School of Animal Husbandry and Dairying SHIATS, Allahabad, India \\ ${ }^{2}$ Associate Professor SHIATS, Allahabad, India \\ ${ }^{3}$ Professor SHIATS, Allahabad, India
}

\begin{abstract}
An experiment was conducted on 81 'day -old' broiler chicks to find out the effect of stocking density and light intensity on feed efficiency of caged broilers. All broiler chicks were kept into cages and managed under similar manage mental conditions. Chicks were randomly divided into nine groups as treatments. viz. $T_{1}\left(2\right.$ Broiler chicks kept under 15 watt light intensity, $T_{2}(2$ Broiler chick kept under 25 watt light intensity, $T_{3}$ (2 Broiler chicks kept under 40 watt light intensity, $T_{4}$ (3 Broiler chick kept under 15 watt light intensity, $T_{5}$ (3 Broiler chick kept under 25 watt light intensity, $T_{6}$ (3 broiler chicks kept under 40 watt light intensity, $T_{7}(4$ broiler chicks kept under 15 watt light intensity, $T_{8}\left(4\right.$ broiler chicks kept under 25 what light intensity and $T_{9}$ (4 broiler chicks kept under 40 watt light intensity) and the chicks of each treatment were further divided into three-sub groups to serve as replicates. All chicks in cage were provided similar standard ration as per NRC (1994). The data on feed consumption and feed conversion ration (FCR) of broiler chicks were recorded, tabulated and statistically analyzed as per Snedecar and Cochran (1994). Mean weekly feed intake of broiler chicks (g) was not significantly influenced by different treatments of stocking density and light intensity. However $T_{8}$ registered highest mean weekly feed intake in broiler chicks. Significantly lower weekly FCR than remaining treatments showing their superiority over rest of the treatments.
\end{abstract}

Keywords: Broiler chicks, stocking density and light intensity, feed efficiency.

\section{Introduction}

Today, poultry is one of the fastest growing segments of the agricultural sector in India. While the production of Agricultural crops has been rising at a rate of 1.5 to 2 percent per annum, that of eggs and broilers has been rising at a rate of 8 to 10 percent per annum. As a result, India is now the worlds fifth largest egg producer and the eighteenth largest producer of broilers. Driving this expansion are a combination of factors-growth in per capita income, a growing urban population and falling real poultry prices.

With the rise of middle class and increased urbanization a major population prefer to go for non vegetarian. Today about 3 million farmers and 15 million agrarian farmers are employed in the poultry industry that are usually growing poultry ingredients for feed and contribute about Rs. 26,000 crore the national income.

The Indian poultry sector with $7.3 \%$ growth in poultry production has witnessed the faster growth of about $6 \%$ in eggs and $10 \%$ in meat production over the last decades among all animal based sectors. The high growth has placed India at fifth position after U.S.A., China, Brazil and Mexico with a production of 2.6 million metric tons chickens meat during 2009-10. Value of output received from poultry meat as per the data of National Account Statistics 2011, CSO, GOI for 2009-10 was Rs. 24756 crores. Indian broiler production growth is estimated at 10 percent per year, with broiler production reaching a record of 3.2 million tons in 2012.

Stocking density is considered as one of the most important environmental factors because of its established effect on growth of broiler chickens. The effect of stocking density in broilers production has a wide range of extreme complexity as many researches have clearly indicated negative effects of high stocking density on production performance; parameters of quality, broiler health and welfare. Stocking density is a concept of interest to the modern poultry misers. It implies how densely birds can be kept together without affecting their production potentials.

Lighting plays a large role in poultry production and bird performance. It is possible to reduce energy costs by making small changes to the lighting on daily operation. A well designed energy efficient lighting intensity system can mean better lighting levels lower energy costs and better performance of broiler chicks. Light intensity has an effect on cannibalism and aggression along with feed and water intake. Light as an environmental factor can affect the physical activity of broiler chickens (Lewis and Morris, 1998).

\section{Materials and Methods}

Eighty one (81) day old-chicks (DOC) of same hatch were procured and reared in battery type cages of Small Animals Laboratory of Sunderesan School of Animal Husbandry and Dairying, SHIATS Allahabad.

The chicks were weighed, by banded and distributed randomly into nine groups as treatments viz. $\mathrm{T}_{1}$ (2 Broiler chick kept under 15 watt light intensity, $\mathrm{T}_{2}$ (2 Broiler chick kept under 25 watt light intensity, $\mathrm{T}_{3}$ (2 Broiler chicks kept under 40 watt light intensity, $\mathrm{T}_{4}$ (3 Broiler chick kept under 15 watt light intensity, $\mathrm{T}_{5}$ (3 Broiler chick kept under 25 watt light intensity, $\mathrm{T}_{6}$ ( 3 broiler chicks kept under 40 watt light intensity, $\mathrm{T}_{7}$ (4 broiler chicks kept under 15 watt light intensity and $\mathrm{T}_{8}$ (4 broiler chicks kept under 25 what light 


\section{International Journal of Science and Research (IJSR) \\ ISSN (Online): 2319-7064 \\ Index Copernicus Value (2013): 6.14 | Impact Factor (2015): 6.391}

intensity and $T_{9}$ (4 broiler chicks kept under 40 watt light intensity. The chicks of each treatment were further divided into three sub-groups to serve as replicates. Self prepared, standard starter ration up to three weeks of age and then broiler finisher ration up to fifth weeks as per BIS (1992), specification for energy and protein were fed.

$\mathrm{Al}$ chicks in cages were provided similar ration. Clean and safe water was made available at all time. The data on body weight, feed consumption and gain in weight of broiler chicks were recorded, tabulated and statistically analyzed using anlaysis of variance technique as per Snedecar and Cochran, (1994).

\section{Results and Discussion}

The mean values of weekly feed intake and feed conversion ratio (FCR) of broiler chicks under different treatments of stocking density and light intensity are summarized in table 1 and Table 2.

The mean body weight of DOC in different treatments of stocking density and light intensity viz. $\mathrm{T}_{1}$ to $\mathrm{T}_{9}$ was 40.00 , 41.33, 41.00, 43.33, 44.00, 43.33, 40.00, 41.33 and 42.33g respectively. The differences in mean body weight of DOC were found non-significant indicating random and unbiased distribution of chicks in cages.

The mean feed intake at one week age of broiler chicks in different treatments viz. $\mathrm{T}_{1}$ to $\mathrm{T}_{9}$ was $161.76,150.42$, 157.42, 159.51, 162.65, 162.53, 161.41, 161.48 and 147.53 g. respectively. The differences in mean feed intake of the broiler chicks at one week of age were found nonsignificant.

The mean feed intake at two week age of broiler chicks in different treatments viz. $\mathrm{T}_{1}$ to $\mathrm{T}_{9}$ was $329,358.34,369.34$, 365.01, 293.87, 317.00, 361.00, 360.67 and 256.49g respectively. The differences in mean feed intake of the broiler chicks at two week of age were found nonsignificant.

The mean feed intake at third week age of broiler chicks in different treatments viz. $\mathrm{T}_{1}$ to $\mathrm{T}_{9}$ was 506.22, 512.33, 521.66, 692.33, 679.61, 602.99, 549.22, 737.33 and 517.75g, respectively. The differences in mean feed intake of the broiler chicks at third weeks of age in $\mathrm{T}_{8}, \mathrm{~T}_{4}, \mathrm{~T}_{5}$ and $\mathrm{T}_{6}$ were found non-significantly effective to obtain higher feed intake. However differences among $T_{7}, T_{3}, T_{9}, T_{2}$ and $T_{1}$ were found non-significant being at par.

The mean feed intake at fourth week age of broiler chicks in different treatments viz. $\mathrm{T}_{1}$ to $\mathrm{T}_{9}$ was 572.07, 669.60, 691.94, 769.04, 646.25, 669.35, 676.16, 645.94 and 750.93g, respectively. The differences in mean feed intake of the broilers at fourth week age in $T_{4}$, and $T_{9}$ were found significant. However differences among $T_{5}, T_{8}$ and $T_{1}$ and also between $T_{3}, T_{7}, T_{2}$ and $T_{6}$ were found non-significant being at par.

The mean feed intake at fifth week age of broiler chicks in different treatments viz. $\mathrm{T}_{1}$ to $\mathrm{T}_{9}$ was 786.70, 741.56,
750.77, 830.99, 943.76, 843.95, 858.59, 1085.69 and 871.05g., respectively. The differences in mean feed intake of the broilers at fifth week age in $T_{8}$ and $T_{5}$ were found significant. However differences among $T_{1}, T_{3}$ and $T_{2}$ and also between $T_{9}, T_{7}, T_{6}$ and $T_{4}$ were found non-significant being at par.

Mean weekly feed intake of broiler chicks in different treatments viz. $\mathrm{T}_{1}$ to $\mathrm{T}_{9}$ was $471.15,486.45,498.23$, 563.38, 545.23, 519.16, 521.28, 598.22 and 508.75g. respectively. The differences in mean weekly feed respectively. The differences in mean weekly feed intake of broiler chicks were found non-significant.

The mean Feed Conversion Ratio (FCR) at one week age of broiler chicks in different treatments viz. $\mathrm{T}_{1}$ to $\mathrm{T}_{9}$ was 1.78 , $1.73,1.61,1.59,1.88,1.64,1.60,1.63$ and $1.63 \mathrm{~g}$, respectively. The differences in mean (FCR) of the broiler chicks of one week age were found non-significant.

The mean FCR at two week age of broiler chicks in different treatments viz. $\mathrm{T}_{1}$ to $\mathrm{T}_{9}$ was $1.81,1.87,1.77,1.61,1.90$, $1.73,1.75,1.65$ and $1.97 \mathrm{~g}$. respectively. The differences in mean FCR at two week of age were found non-significant.

The mean FCR at third week age of broiler chicks in different treatments viz. $\mathrm{T}_{1}$ to $\mathrm{T}_{9}$ was $1.94,1.88,1.83$, 1.69, $1.92,1.74,1.84,1.66$ and 1.82 g. respectively. The differences in mean FCR of the broiler chicks at third week age were found non-significant.

The mean FCR at fourth week age of broiler chicks in different treatments viz. $\mathrm{T}_{1}$ to $\mathrm{T}_{9}$ was $2.08,1.89,1.87,1.83$, $1.94,1.78,1.89,1.71$, and $1.85 \mathrm{~g}$. respectively. The differences in mean FCR of the broiler chicks of age were found non-significant.

The mean FCR at fifth week age of broiler chicks in different treatments viz. $\mathrm{T}_{1}$ to $\mathrm{T}_{9}$ was $2.11,1.94,1.90,1.84$, $2.26,1.94,1.98,1.72$ and $1.88 \mathrm{~g}$, respectively the differences in mean FCR of the broiler chicks at fifth week age in $T_{5}$ were found significant. However differences among $T_{3}, T_{9}$, $\mathrm{T}_{4}$, and $\mathrm{T} 8$ and also between $\mathrm{T}_{1}, \mathrm{~T}_{7}, \mathrm{~T}_{2}$ and $\mathrm{T}_{6}$ were found non-significant being at par.

The mean weekly FCR of broiler chicks in different treatments viz. $\mathrm{T}_{1}$ to $\mathrm{T}_{9}$ was $1.94,1.86,1.80,1.71,1.98$, 1.77, 1.81, 1.67 and 1.83 g., respectively and the differences in mean weekly FCR of the broiler chicks were found significant. However differences among $\mathrm{T}_{4}$ and $\mathrm{T}_{8}$ and between $T_{9}, T_{7}, T_{3}$ and $T_{6}$ and also between $T_{1}$ and $T_{2}$ were found non-significant being at par.

\section{Conclusion}

Based on results of the experiments it may be concluded that stocking density and light intensity had significant effect on feed conversion ratio (FCR) whereas feed intake of caged broiler was non-significantly influenced by different treatments of under treatments of the caged broilers. 


\section{International Journal of Science and Research (IJSR) \\ ISSN (Online): 2319-7064 \\ Index Copernicus Value (2013): 6.14 | Impact Factor (2015): 6.391}

Table 1: Means values of various treatments under different treatments of the experiments of the stocking density and light intensity on the performance of the caged broilers.

\begin{tabular}{|c|c|c|c|c|c|c|c|c|c|c|}
\hline \multirow[t]{2}{*}{ Parameters } & \multicolumn{9}{|c|}{ Treatments } & \multirow[t]{2}{*}{ Results } \\
\hline & $\mathrm{T}_{1}$ & $\mathrm{~T}_{2}$ & $T_{3}$ & $\mathrm{~T}_{4}$ & $T_{5}$ & $\mathrm{~T}_{6}$ & $\mathrm{~T}_{7}$ & $\mathrm{~T}_{8}$ & $\mathrm{~T}_{9}$ & \\
\hline Body weight of DOC in (g) & $40.00^{\mathrm{a}^{* *}}$ & $41.33^{\mathrm{a}}$ & $41.00^{\mathrm{a}}$ & $43.33^{\mathrm{a}}$ & $44.00^{\mathrm{a}^{*}}$ & $43.33^{\mathrm{a}}$ & $40.00^{\mathrm{a}^{* * \mathrm{x}}}$ & $41.33^{\mathrm{a}}$ & $42.33^{\mathrm{a}}$ & NS \\
\hline Mean weekly feed intake of broiler chicks in (g) & $471.15^{\mathrm{a}^{* *}}$ & $486.45^{a}$ & $498.23^{\mathrm{a}}$ & $563.38^{\circ}$ & $454.23^{\mathrm{a}}$ & $519.16^{\mathrm{a}}$ & $521.28^{\mathrm{a}}$ & $598.22^{\mathrm{a}^{*}}$ & $508.75^{\mathrm{a}}$ & NS \\
\hline Mean weekly FCR of broiler chicks in (g) & $1.94^{\mathrm{b}}$ & $1.86^{\mathrm{b}}$ & $1.80^{\mathrm{c}}$ & $1.71^{\mathrm{d}}$ & $1.98^{\mathrm{d}^{*}}$ & $177^{\mathrm{C}}$ & $1.81^{\mathrm{C}}$ & $1.67^{\mathrm{d} * *}$ & $1.83^{\mathrm{C}}$ & S \\
\hline
\end{tabular}

$* *=$ Lowest

Note : Figures with similar alphabets show non-significant difference between the values within the parameter.
Week-wise mean values of feed intake (g) and FCR (g) of broiler chicks reared under different treatment of stocking density and light intensity.

Table 2: Week-wise mean values of feed intake (g) and feed conversion ratio (FCR) in (g) of broiler chicks reared under different treatments of stocking density and light intensity.

\begin{tabular}{|c|c|c|c|c|c|c|c|c|c|c|c|}
\hline \multirow[t]{2}{*}{ Treatments } & \multirow{2}{*}{$\begin{array}{l}\text { Body weight } \\
\text { of DOC in } \\
\text { (g) }\end{array}$} & \multicolumn{5}{|c|}{ Mean weekly feed intake of broiler chicks in (g) } & \multicolumn{5}{|c|}{$\begin{array}{l}\text { Mean weekly feed conversion ration of broiler chicks in } \\
(\mathrm{g})\end{array}$} \\
\hline & & $\begin{array}{c}1 \text { week } \\
\text { age }\end{array}$ & $\begin{array}{l}2 \text { week } \\
\text { age }\end{array}$ & $\begin{array}{l}3 \text { week } \\
\text { age }\end{array}$ & $\begin{array}{l}4 \text { week } \\
\text { age }\end{array}$ & $\begin{array}{l}5 \text { week } \\
\text { age }\end{array}$ & $\begin{array}{l}1 \text { week } \\
\text { age }\end{array}$ & $\begin{array}{l}2 \text { week } \\
\text { age }\end{array}$ & $\begin{array}{l}3 \text { week } \\
\text { age }\end{array}$ & $\begin{array}{l}4 \text { week } \\
\text { age }\end{array}$ & $\begin{array}{l}5 \text { week } \\
\text { age }\end{array}$ \\
\hline $\mathrm{T}_{1}$ & $40.00^{\mathrm{a}^{* *}}$ & $161.76^{\mathrm{a}}$ & $329.00^{\mathrm{a}}$ & $506.22^{\mathrm{c}^{* *}}$ & $572.07^{\mathrm{c}^{* *}}$ & $786.70^{\mathrm{d}}$ & $1.78^{\mathrm{a}}$ & $1.81^{\mathrm{a}}$ & $1.94^{\mathrm{a}^{*}}$ & $2.08^{\mathrm{a}^{*}}$ & $2.11^{\mathrm{b}}$ \\
\hline $\mathrm{T}_{2}$ & $41.33^{\mathrm{a}}$ & $150.42^{\mathrm{a}}$ & $358.34^{\mathrm{a}}$ & $512.33^{\mathrm{C}}$ & $669.60^{\mathrm{b}}$ & $741.56^{\mathrm{d}^{\mathrm{*} *}}$ & $1.73^{\mathrm{a}}$ & $1.87^{\mathrm{a}}$ & $1.88^{\mathrm{a}}$ & $1.89^{\mathrm{a}}$ & $1.94^{\mathrm{b}}$ \\
\hline $\mathrm{T}_{3}$ & $41.00^{\mathrm{a}}$ & $157.42^{\mathrm{a}}$ & $369.34^{\mathrm{a}^{*}}$ & $521.66^{c}$ & $691.94^{\mathrm{b}}$ & $750.77^{\mathrm{d}}$ & $1.61^{\mathrm{a}}$ & $1.77^{\mathrm{a}}$ & $1.83^{\mathrm{a}}$ & $1.87^{\mathrm{a}}$ & $1.90^{\mathrm{c}}$ \\
\hline $\mathrm{T}_{4}$ & $43.33^{\mathrm{a}}$ & $159.51^{\mathrm{a}}$ & $365.01^{\mathrm{a}}$ & $692.33^{\mathrm{d}}$ & $769.04^{\mathrm{d}}$ & $830.99^{\mathrm{C}}$ & $1.59^{\mathrm{a}^{* *}}$ & $1.61^{\mathrm{a}^{* *}}$ & $1.69^{\mathrm{a}}$ & $1.83^{\mathrm{a}}$ & $1.84^{\mathrm{C}}$ \\
\hline $\mathrm{T}_{5}$ & $44.00^{\mathrm{a}^{*}}$ & $162.65^{\mathrm{a}^{*}}$ & $293.87^{\mathrm{a}}$ & $679.61^{\mathrm{a}}$ & $646.25^{c}$ & $943.76^{b}$ & $1.88^{\mathrm{a}^{*}}$ & $1.90^{\mathrm{a}}$ & $1.92^{\mathrm{a}}$ & $1.94^{\mathrm{a}}$ & $2.26^{\mathrm{a}^{*}}$ \\
\hline $\mathrm{T}_{6}$ & $43.33^{\mathrm{a}}$ & $162.53^{\mathrm{a}}$ & $317.00^{\mathrm{a}}$ & $602.99^{b}$ & $669.35^{b}$ & $843.95^{\mathrm{C}}$ & $1.64^{\mathrm{a}}$ & $1.73^{\mathrm{a}}$ & $1.74^{\mathrm{a}}$ & $1.78^{\mathrm{a}}$ & $1.94^{\mathrm{b}}$ \\
\hline $\mathrm{T}_{7}$ & $40.00^{\mathrm{a}^{* *}}$ & $161.41^{\mathrm{a}}$ & $361.00^{\mathrm{a}}$ & $549.22^{\mathrm{C}}$ & $676.16^{\mathrm{b}}$ & $858.59^{c}$ & $1.60^{\mathrm{a}}$ & $1.75^{\mathrm{a}}$ & $1.84^{\mathrm{a}}$ & $1.89^{\mathrm{a}}$ & $1.98^{\mathrm{b}}$ \\
\hline $\mathrm{T}_{8}$ & $41.33^{a}$ & $161.48^{\mathrm{a}}$ & $360.67^{\mathrm{a}}$ & $737.33^{\mathrm{e}^{*}}$ & $645.94^{\mathrm{C}}$ & $1085.69^{\mathrm{d}}$ & $1.63^{\mathrm{a}}$ & $1.65^{\mathrm{a}}$ & $1.66^{\mathrm{a}^{* *}}$ & $1.71^{\mathrm{a}^{* *}}$ & $1.72^{\mathrm{C}^{\mathrm{y}}}$ \\
\hline $\mathrm{T}_{9}$ & $42.33^{\mathrm{a}}$ & $147.33^{\mathrm{a}^{* \mathrm{x}}}$ & $256.49^{\mathrm{a}^{* *}}$ & $517.75^{c}$ & $750.93^{\mathrm{a}}$ & $871.05^{\mathrm{c}}$ & $1.63^{\mathrm{a}}$ & $1.97^{\mathrm{a}^{*}}$ & $1.82^{\mathrm{a}}$ & $1.85^{\mathrm{a}}$ & $1.88^{\mathrm{C}}$ \\
\hline
\end{tabular}

\section{Acknowledgement}

Authors are thankful to department of Sundaresan school of Animal Husbandry and Dairying, SHIATS in Allahabad for providing required help to carry out the experiments.

\section{References}

[1] BIS, 1992.National requirement of poultry. Butrau of India standards. I.S. 13574.

[2] Lewis, P.S.and Morris, T.R. 1998.Light intensity and performance of domestic pullets. World's Poultry Science Journal, 55:241-250.

[3] NRC (National Research Council), 1994.Nutrient Requirements of Poultry. $9^{\text {th }}$ Rev. Edn. National Academy Press, Washington, DC.

[4] Snedecor, G.W. and Cochran, W.G. 1994. Statistical Methods $8^{\text {th }}$ edn, lowa state university press/Ames, Lowa50010.

[5] Tucker, S.A. and Charles, D.R. 1993. Light intensity. Intermittent lighting and feeding regimen during rearing as affecting egg production and egg quality, British Poultry Science, 34:255-266.

[6] Winechell, W. 2001.Lighting for poultry housing, Canada, Plan Service. 